Volume 11 Number 3, July-September 2017: pp. 266-288. Copyright (c) 2017 FIAT JUSTISIA. Faculty of Law, Lampung University, Bandarlampung, Lampung, Indonesia. ISSN: 1978-5186 | e-ISSN: 2477-6238.

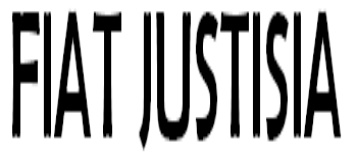

Fiat Justisia is licensed under a Creative Commons Attribution 4.0 International License, which permits unrestricted use, distribution, and reproduction in any medium, provided the original work is properly cited.

\title{
The Protection of Human Rights in Indonesian Constitutional Law after the Amendment of the 1945 Constitution of the Republic of Indonesia
}

\author{
Leli Tibaka \\ International Law Department, \\ Faculty of Law, University of Tadulako \\ lelitibaka@yahoo.com
}

\section{Rosdian}

International Law Department, Faculty of Law,

University of Tadulako

dian_recht@yahoo.co.id

\begin{abstract}
The amendment to the 1945 Constitution of the Republic of Indonesia has shown progress in respecting, protecting and fulfilling human rights in Indonesia. It is proven from the advanced provisions that have set the human rights material, starting from the affirmation of fundamental rights, individual rights, social rights, solidarity rights, and even the assertion of rights included in the category of not-derogable rights in the Second Amendment to the 1945 Constitution. The urgency of the Constitution 1945 as written constitution due to its status as the ultimate instrument to determine a norm (law), action or government policy, so it will not violate human rights and constitutional rights of the citizens. Thus, the Constitution is an important instrument in term of guaranty and ensuring that human rights within the Republic of Indonesia are protected, even though the source of human rights is not actually derived from the State but naturally originated from natural law, whether its universal validity is either affirmed or not in the Constitution. It shows progress in the level of regulation and protection of human rights in Indonesia.

Related to the guarantee of the protection of human rights, one of the important material of the 1945 Constitution of the Republic of Indonesia
\end{abstract}


is the presence of a new judicial institution called the Constitutional Court, in addition to the Supreme Court. The existence of the Constitutional Court in Indonesia is an improvement in maintaining and upholding the Constitution and protecting human rights. Hence, the Constitutional Court referred to as "the Protector of Human Rights." Protection of human rights is carried out through the exercise of authority as defined in Article 24C Paragraph (1) of the 1945 Constitution which is to review an Act against the Constitution, to judge on authority disputes of state institutions whose authorities are granted by the Constitution, to judge on the dissolution of a political party, and to judge on disputes regarding the result of a general election. Also, Article 24C Paragraph (2) obliges the Constitutional Court to render a judgment on the petition of the People's Representative Council regarding an alleged violation by the President and the Vice President according to the Constitution.

Keywords: Human Rights, Constitutional Law, Amendment to the Constitution.

\section{A. Introduction}

Human rights are the rights that human beings possess exclusively because they are human. Humanity has it not because it is given to them by society or by positive law of the State, but solely by his/her dignity. In this sense, even though everyone is born with different skin color, gender, language, culture, and citizenship, he/she still has those rights. It is the universal nature of these rights. Also of being universal, those rights cannot be revoked (inalienable), means that as bad as any treatment that has been experienced by a person or no matter how cruel a person is, he/ she will not cease to be human and therefore retain those rights. In other words, those rights are attached to him as a human being. ${ }^{1}$ Human rights are the basic rights that inherently belong to a person, its universal and therefore must be protected, respected, retained, and should not be ignored, diminished, or deprived by anyone, including the State itself.

The original idea of human rights as described above stem from the theory of natural rights. The theory of natural rights begins with natural law theory, the latter of which can be traced back to ancient times with Stoic philosophy down to modern times through the writings of naturalist of Saint Thomas Aquinas. Hugo de Groot (a Dutch jurist who was named as the "father of International Law" or better known by his Latin name Grotius) further developed Aquinas's natural law theory by breaking down its theistic

\footnotetext{
${ }^{1}$ Knut D. Asplund, Suparman Marzuki, Eko Riyadi (Editors). Hukum Hak Asasi Manusia (The Human Rights Law. Translated by the Authors) / Rhona K. M. Smith, et.al., Pusat Studi Hukum dan Hak Asasi Manusia, Yogyakarta: Universitas Islam Indonesia, (2008), p.11.
} 
origins and making it a product of rational secular thought. It is on this basis that John Locke proposes his thoughts on the theory of natural rights underlying the emergence of the revolution of rights in revolutionary events that erupted in England, the United States and France in the seventeenth and eighteenth centuries. ${ }^{2}$ In his book "The Second Treatise of Civil Government and a Letter Concerning Toleration" Locke proposed a postulated thought that all individuals are endowed with the inherent nature of life, liberty and ownership, which is their own and cannot be revoked or stripped off by the state. The protection of this inalienable right is left to the state through a 'social contract', but with the provision affirmed by John Locke that if the state authorities neglect the social contract by violating the individual's natural rights, the people of the state is free to depose the ruler and replace it with a government willing to respect those rights". ${ }^{3}$

Through this theory of natural rights, the existence of pre-positive individual rights gained strong recognition. The instrument of recognition intended by John Locke as a social contract is the Constitution of a state, in which it guarantees, protects and fulfills the basic human rights. But it is worth noting as previously states that the Constitution is not the source of human rights because human rights derived naturally from the basic nature of human existence. The theory above serves as the basis for the protection of human rights as one of the important principles in the context of the constitutional law of state and government. The constitutional guarantee for the protection of human rights held paramount importance in the constitutional law. Based on the classical history account, two words are closely related to our current understanding of the "constitution" term, the ancient Greek word "politeia', and the Latin word "constitution" which is also related to the word "jus." Both words "politeia" and "constitution" are the beginning of the idea of constitutionalism and the relationship between the two terms in history expressed by humanity. ${ }^{4}$

Moreover, the constitutional law precedes the existence of the state organization. As Thomas Paine said that the Constitution existed first rather than the existence of government because the government was formed under the provisions of the Constitution. The affirmation of the constitution as a social contract is also further advanced by Thomas Paine that: "a constitution is not the act of government, but of a people constituting a government and a government without a constitution is a power without right." The Constitution is not a regulation made by the government, but it is a

\footnotetext{
${ }^{2}$ Ibid.

${ }^{3}$ Ibid., p. 13.

${ }^{4}$ Jimly Asshiddiqie, Pengantar Ilmu Hukum Tata Negara (Introduction to the Indonesian Constitutional Law. Translated by the Authors), Bandung: Rajagrafindo Persada, (2009), p. 161.
} 
regulation made by the people to govern the government, and the government itself without the constitution equals power without authority. ${ }^{5}$

The importance of a constitution in a State also shown in French term "constituent" which means "to form" or "the establishment of a state or compile and declare a State", 6 whereas, in Latin, the word "constitution" means "making something standing" or "establishing", and the "constitutional" means "everything that has been established"7 (the State). In Indonesia, the term "constitution" is a direct translation of the Dutch language "grondwet." The word "wet" means "act," and "grond" means "land/base" "when translated into the Indonesian language. English speaking countries and Indonesia commonly use the term "constitution." In practice, the meaning of "constitution" could be more broadly than the definition of the "basic law," but there are also opinions stating that the definition of the "constitution" is the same as the "basic law." For the political science scholars, the term "constitution" is used in the broader sense, that is, the whole of written and unwritten rules governing how a government is organized in a society. ${ }^{9}$

The notion that the Constitution is the same as the basic law is never unanimously approved. Some scholars explain that the definition of "constitution" is the same as the "basic law" while others held the notion that "constitution" is not the same as the "basic law." The latter opinion was following, for example, F. Lasalle and Herman Heller, while the adherents of the first opinion including James Bryce and C. F. Strong. Jimly Asshiddiqie states that the constitution is the basic law, the basic norm and the highest norm in the state system. However, as a law, the constitution itself is not always written (geschreven constitution). The term "written constitution" is usually equated with the Constitution in the narrow sense, while the term "unwritten constitution" equated with the Constitution in the broader sense. This paper uses both of these terms by the understanding and the context. When speaking in general about the basic law, it is used the term of the "constitution," while talking about the written constitution, it is used as the term of the Constitution. The relation to the concept of International Law and even the Human Rights Law itself in viewing human rights and constitution in theoretical and normative level as stated above is quite

\footnotetext{
${ }^{5}$ Ibid.

${ }^{6}$ Wirdjono Prodjodikoro, Asas-Asas Hukum Tata Negara di Indonesia (The Principles of Indonesian Constitutional Law. Translated by the Authors), Jakarta: Dian Rakyat, (1989), p.10.

${ }^{7}$ Dahlan Thaib, Jazim Hamidi and Nikmatul Huda, Teori dan Hukum Konstitusi (Theory and Constitutional Law. Translated by the Authors), Jakarta: Rajagrafindo Persada, (2008), pp. 78.

${ }^{8}$ Ibid.

${ }^{9}$ Ibid.
} 
different from the ideas and the practices in Indonesian Constitutional Law. It is the basis of critical analysis in the book of Human Rights Law published by the Center for Human Rights Studies of Indonesia Islamic University which is:

Because Human Rights Law is given as a part of the constitutional law, it is inevitable that the material being taught is also limited as an accessory of constitutional law, which is taught as one of the essential elements of the concept of state law (rechtsstaat). The matter of concern is when there is a process of reviving the idea of Soepomo's integral State in the constitutional law which is regarded as the state of mind of the state of Indonesia. This process leads to the teaching of human rights in law faculties placed in the perspective of the integral state, which places human rights into the term "rights of the citizen." Such an approach and orientation leads to "accidents" in the teaching of human rights at various universities in Indonesia that human rights are constantly discussed with suspicion, regarded as self-indulgent, liberal, and reflective "western" values. ${ }^{10}$

It further explained that the discourse developed by looking at human rights as empowerment of protected individuals confronts the power of the state and its society are rarely shown, as developed by the human rights theory after the World War II. Its external environment exacerbated this "accident"; an authoritarian political system developed during the Indonesian New Order regime. It is understandable that in the New Order era, human rights were placed as a threat to the political stability, so the government ruled a "black campaign" on human rights issues by portraying it as "fourth generation communist" or "Western minion."11 Historically, the concept of protection and promotion of human rights has been started since the drafting of the 1945 Constitution by BPUPKI with the results as regulated in the 1945 Constitution (first period). Human rights in the 1945 Constitution are regulated briefly, very simply, and are oriented towards civil rights, not human rights. ${ }^{12}$

This affirmation of the teaching orientation and the understanding of human rights has shifted after Indonesian reform of 1998 and through the amendment of the 1945 Constitution which has accommodated the regulation of advanced human rights material. Starting from rights that are

\footnotetext{
${ }^{10}$ Knut D. Asplund, Suparman Marzuki. Eko Riyadi, Op.Cit., p. 5.

${ }^{11}$ Ibid.

${ }^{12}$ Majda El Muhtaj, Jaminan Konstitusi atas Hak Asasi Manusia : Kajian terhadap UUD yang Pernah Berlaku di Indonesia Sejak Tahun 1945 Sampai Dengan Amandemen ke Empat Tahun 2002 (Constitutional Guarantee on Human Rights : Study to Indonesian Constitution Since 1945 Until The Fourth Amendment in 2002. Translated by the Authors), Medan: Thesis, Post Graduated Program The University of North Sumatera, (2002), p. vii.
} 
categorized as fundamental rights ${ }^{13}$, individual/personal rights ${ }^{14}$, up to the social rights. Human Rights are regulated in Chapter XA on Human Rights consisting of 10 Articles starting from Article 28A to Article 28J. ${ }^{15}$ The recognition of human rights in the 1945 Constitution after the amendment shows that the 1945 Constitution as the written constitution of Indonesia has played a very important role in the promotion, the protection and the fulfillment of human rights. The Constitution is the supreme law, under which other legal norms serve to outline the provisions of the constitution including the regulation and further elaboration of more operational and concrete human rights guarantees and safeguards.

In order to ensure that the Constitution is fully exercised in terms of human rights protection and for guarantee that the regulations under the Constitution are in accordance or not contradictory to the Constitution itself, it is necessary to ensure the legal certainty and the judicial institution to uphold and to interpret the Constitution as a measure in the judgment of an Act, whether the Act is contradictory or incompatible with the Constitution. ${ }^{16}$ To realize this, through the Third Amendment of the 1945 Constitution (Article 24), the Constitutional Court is established to maintain and to uphold the Constitution and the constitutionalism, ensuring the enforcement, protection and the fulfillment of human rights. ${ }^{17}$ This review will further discuss the existence of the 1945 Constitution and its amendment and the existence of the Constitutional Court as the main instrument for the realization of the protection and the fulfillment of human rights in Indonesia. The question then is what the urgency of the amendment to the 1945 Constitution as the written constitution and the main instrument of human rights protection in Indonesia is? What is the function of the Constitutional Court as "the protector of human rights" in Indonesia?

\section{B. Research Methods}

This research uses normative legal research method or literature studies because it examines and analyzes the protection of human rights in Indonesian Constitutional Law after the Amendment of the 1945

\footnotetext{
${ }^{13}$ Article 28A, Second Amendment of 1945 Constitution.

${ }^{14}$ Article 28, Second Amendment of 1945 Constitution.

${ }^{15}$ Majda El Muhtaj, Op. Cit., p. vii.

${ }^{16}$ Jimly Asshiddiqie, Gagasan Dasar tentang Konstitusi dan Mahkamah Konstitusi (Basic Idea on Constitution and Constitutional Court. Translated by the Authorss), in Sri Rahayu Oktoberina and Niken Savitri (Editors) Butir-Butir Pemikiran dalam Hukum, Memperingati 70 Tahun Prof. Dr. B. Arief Sidharta (Pieces of Thoughts on Law, Celebrating the 70 Years of Prof. Dr. B. Arief Sidharta), Bandung: Revika Aditama, (2008), p. 207.

${ }^{17}$ Abdul Latif, Fungsi Mahkamah Konstitusi Upaya Mewujudkan Negara Hukum Demokrasi (The Constitutional Court Function in Order to Fulfill the Democratic Law State, Translated by The Authors), Jakarta: Total Media, (2009), p. 5.
} 
Constitution of the Republic of Indonesia. This method uses primary, secondary and tertiary legal materials in its process. The primary legal material is the 1945 Constitution of the Republic of Indonesia. Secondary legal materials are legal literature explaining and analyzing the laws and regulations related to this study. Tertiary legal materials are including dictionary and encyclopedia that help in deciphering some of the terms or concepts used in this research.

The statutory approach was used to analyze the 1945 Constitution of the Republic of Indonesia and the conceptual approach that is moved from the views and doctrines that developed in the science of law, for example, the concept of Constitution, human rights, and other related material. ${ }^{18}$ Based on the legal materials such as legislation, theories, and doctrines that are obtained, processed and interpreted to answer the issues raised on the subject.

\section{Discussion}

\section{The 1945 Constitution of the Republic of Indonesia: The Written Constitution and the Main Instrument for the Protection of Human Rights in Indonesia}

A Constitution is an essential instrument that must exist in every State as the guardian and the protector of human rights. The essence of constitutionalism view is a limitation to the power of the State (government) so that the State (government) does not hold the absolute power and always guarantee and protect the human rights. ${ }^{19}$ All Constitutions always make power as the center of attention, because it is necessary to regulate and to limit the power. Through the Constitution and the basic law, constitutionalism will be implemented, where the essence and definition of constitutionalism is a concept of limiting the power and guarantee of people's rights through the constitution. Carl J. Friedrich explains that: "constitutionalism is an institutionalized system of effective, regularized restrains upon governmental action." 20 The consensus that guarantees the upholding of constitutionalism in modern times is generally understood to rely on three elements of consensus, namely: ${ }^{21}$

\footnotetext{
${ }^{18}$ Peter Mahmud Marzuki, Penelitian Hukum (Law Research. Translated by the Authors), Jakarta: Kencana, (2005), p. 95.

19 Jazim Hamidi dan Malik, Hukum Perbandingan Konstitusi (Law of Constitutional Comparison. Translated by the Authors), Jakarta: Prestasi Pustaka Publisher, (2008), p. 15.

20 Jimly Asshiddiqie, Konstitusi dan Konstitusionalisme Indonesia di Masa Depan (The Future of Indonesia Constitution and Constitutionalism. Translated by the Authorss), Jakarta: Center of Constitutional Law Study, Faculty of Law, University of Indonesia, (2002), p. 25.

${ }^{21}$ Ibid., pp. 25-26.
} 
a. The consensus of the general purpose or ideals (general purpose of society or general acceptance of the same philosophy of government);

b. Consensus on the rule of law as the foundation of government or the administration of the state (the basis of government);

c. Consensus on the form of institutions and procedures of the constitution.

The first consensus concerning the common aspiration determines the establishment of constitution and constitutionalism in a state. Therefore, in a society, to ensure unity within the framework of statehood, it is necessary to formulate a common goal or an ideology as the state philosophy or staatsidee which serves as a filosofische grondslag, in Indonesia named Pancasila, meaning five precepts or five basic principles for achieving or realizing the four state goals listed at the Fourth Paragraph of 1945 Constitution Preamble. It is in line with Moh. Yamin expression about the constitutionalism of Pancasila, which is stated as follows following: ${ }^{22}$

"Despite repeated changes in the constitution, during the Indonesian national revolution, one thing that continues to be maintained is Pancasila. The doctrine of Pancasila has long been known in Indonesia, as a philosophical ground for the foundation of the establishment of the Indonesian state. The God, the Humanity, the Fair of Nationality, the People (Democracy), and the Fair of Social Justice, are the five basic elements that are considered capable of maintaining the existence of Indonesian constitutional building. Pancasila became a national consensus that guarded the establishment of Indonesian constitutionalism."

The second consensus talks about the basis of government. It stands above the law and the constitution. It relates to the principle of the rule of law. Law is seen as a unified system which at its peak there is an understanding of the basic law which is a constitution either in the sense of a written or unwritten text. The Constitution is the ultimate guidance in deciding everything that should be based on the law. The third consensus deals with several things: the building of state organs and the procedures governing its power; the relations between the organs of the state to each other, and the relations between the organs with the citizens. With the consensus, the contents of the constitution can be easily formulated because it truly reflects the common desire about state institutions and constitutional mechanisms that will be developed within the framework of the life of a constitutional state.

\footnotetext{
${ }^{22}$ Muh. Yamin. Proklamasi dan Konstitusi (Proclamation and Constitution. Translated by the Authors). Jakarta: Djambatan, (1951), pp. 108-116.
} 
The consensus above essentially concerns the principle of regulation and limitation of the power within the state known as constitutionalism. According to ${ }^{23}$ the meaning or value contained in constitutionalism or Constitution-based principles must contain at least two things:

a. Arranging the boundaries of the role of the State or The Government in interfering with the people and the society association;

b. Legal guarantees of rights, civil or individual rights, political rights or social rights as it is naturally inherent to every human both as individual and social beings.

The further explanation that in addition to limiting the role and the function of the state in the life of society, the principle of the state based on the constitution and the law becomes the basis of establishing legal order and law enforcement. The constitutional state lays the constitution as "the higher law and "the fundamental law." As a series of supreme and fundamental rules of law, all other rules of law must be made by and should not be contrary to the principles and the rules of the constitution. All lower rules should not diverge and contradict with the higher rules. ${ }^{24}$ Theoretically, the fundamental thing which is seen as an important and most prominent foundation for the existence of the Constitution in a State is the desire to guarantee human rights and to control the power of the State. Through the constitutional rules, it is expected that there will be no arbitrariness of the State (government) against the rights of the citizens. ${ }^{25}$

Considering the importance role of the constitution in a State especially as an instrument in ensuring the embodiment of the protection, the respectability and the fulfillment of human rights, it must be ensured that the Constitution has formulated the norms that also guarantee, protect and fulfill human rights and ensure that all human rights are protected through legal remedies mechanism. According to J. G. Steenbeek as argued by Sri Soemantri, it is because generally, the Constitution contains three main points as follows: ${ }^{26}$

a. The guarantee of human rights and citizen/civil rights;

b. The establishment of a fundamental constitutional structure of the state;

c. The division and the restriction of fundamental constitutional duties.

\footnotetext{
${ }^{23}$ Bagir Manan, Teori dan Politik Konstitusi (Theory and Political Constitution. Translated by the Authors), Yogyakarta: FH-UII Press, 2004, p. 238.

${ }^{24}$ Ibid., p. 239.

${ }^{25}$ Jazim Hamidi and Malik, Op. Cit., p. 15.

${ }^{26}$ Sri Soemantri M, Prosedur dan Sistem Perubahan Konstitusi (The Procedure and System of Constitution Amendment. Translated by the Authors). Second Edition, First Printing, Bandung: Alumni, (2009), pp. 59-60.
} 
The Republic of Indonesia uses the 1945 Constitution of the Republic of Indonesia as the written constitution. After the amendment, the official text of the 1945 Constitution consists of:

a. The 1945 Constitution of the Republic of Indonesia;

b. The First Amendment to the 1945 Constitution of the Republic of Indonesia;

c. The Second Amendment to the 1945 Constitution of the Republic of Indonesia;

d. The Third Amendment to the 1945 Constitution of the Republic of Indonesia;

e. The Fourth Amendment to the 1945 Constitution of the Republic of Indonesia.

The regulation of human rights material in the 1945 Constitution should reflect the ideal provision of the constitution in ensuring protection, respectability, and fulfillment of human rights. The provisions in the 1945 Constitution which became an important foundation in implementing a constitutional state that ensures the protection of human rights is regulated in the Second Amendment, which aims to refine the formulation of human rights. One of the principles of constitutionalism to be realized through the amendment of this Constitution focuses on initiating "the Bill of Rights" in the actual text of the articles. Several provisions in the amendment to the 1945 Constitution are related to and support the protection of human rights, namely:

a. Article 1 Paragraph (2) of The Third Amendment to the 1945 Constitution of the Republic of Indonesia affirms that "Sovereignty shall be vested in the hands of the people and be executed according to the Constitution." It demonstrates the principle of constitutional supremacy that supersedes the supremacy of Parliament (MPR) adopted before the amendment of the 1945 Constitution. The people are the source of supreme authority, and the implementation of the highest sovereignty is through the Constitution (the principle of constitutional democracy).

b. Affirmation that the State of Indonesia is a State of law as stated in Article 1 Paragraph (3) of The Third Amendment to the 1945 Constitution of the Republic of Indonesia.

Article 1 Paragraph (2) and Paragraph (3) are closely related, in which the State of Indonesia understands democracy based on the Constitution and the Constitution must also be democratic. Both of the provisions above are very important in upholding human rights, although in fact human rights is not originally derived from the formulation of the articles of the Constitution, but without formulation and affirmation in the Constitution, as happened in the era of the Old Order and the New 
Order through the 1945 Constitution before the change, we cannot expect the human rights and citizen/civil rights to be upright, protected and fulfilled.

The specific articles set out clearly about human rights are listed in Chapter XA under the title HUMAN RIGHTS consisting of 10 Articles, namely:

a. The setting of absolute fundamental rights in Article 28A that "Every person shall be entitled to defend his/her life and living." The rights to live in this article as defined in Article 28H Paragraph (1) is classified as non-derogable rights, i.e., rights that cannot be reduced under any circumstances. In practice, however, the Constitutional Court in Decision Number 2-3/PUU-V/2007 regarding Review of Law No. 22 on 1997 of Narcotics has decided that the validity of this article (the rights to life) is not absolute and all rights can be limited and reduced by the State.

b. Individual Rights and Children Rights, Article 28B Paragraph (1) states "Every person shall be entitled to establish a family and to further descendants through legal marriage." Paragraph (2) states "Every child shall be entitled to viability, to grow up, and to develop as well as be entitled to protection against violence and discrimination." As an elaboration of this provision, the government sealed the Law No. 23 on 2002 of Child Protection and also, the establishment of the Child Protection Commission through the Presidential Decree No. 77 on 2003.

c. The rights to the fulfillment of basic needs and the rights to development, Article 28C Paragraph (1) states "Every person shall be entitled to self-development through the fulfillment of his/her basic needs, be entitled to acquire education and to obtain the benefit of science and technology, arts and culture, for the sake of enhancing his/her quality of life and for the sake of the welfare of mankind". Paragraph (2) also states "Every person shall be entitled to selfadvancement in the struggle of his/her rights collectively to develop the society, the nation, and his/her country."

d. The rights to the recognition of equality before the law and the right to work, Article 28D Paragraph (1) states "Every person shall be entitled to recognition, guaranty, protection, and equitable legal certainty as well as an equal treatment before the law." Paragraph (2) states "Every person shall be entitled to work as well as to obtain reward and just and decent treatment in work relationship." Paragraph (3) states "Every citizen shall be entitled to obtain equal opportunity in the government," and Paragraph (4) also states "Every person shall be 
entitled to citizenship status." In Indonesia, citizenship is incorporated in Law No. 12 on 2006.

e. Freedom of religion and expression, rights of solidarity, union of assembly is stated in Article 28E Paragraph (1) that "Every person shall be free to embrace a religion and to worship according to his/her religion, to choose education and teaching, to choose work, to choose citizenship, to choose a place to reside in the territory of the state and to leave it, as well as be entitled to return". Paragraph (2) states "Every person shall be entitled to the freedom to be convinced of a belief, to express thought and attitude by his/her conscience." Paragraph (3) also states "Every person shall be entitled to the freedom to associate, to assemble, and of expression."

f. The freedom of access to public information, according to Article 28F "Every person is entitled to communicate and to obtain information for the development of his/her personality and social environment, as well as be entitled to seek, to obtain, to own, to store, to process, and to convey the information by means of all kinds of available channels".

g. The rights to personal and property protection as regulated in Article 28G Paragraph (1) "Every person shall be entitled to the protection of his/her control, as well as be entitled to feel secure and be entitled to protection against threat of fear to do or omit to do something is his/her fundamental rights". Paragraph (2) states "Every person is entitled to be free from torture or the treatment that humiliates human dignity and be entitled to the right to obtain political asylum from another country."

h. The right to welfare, affirmative action, social security and property as stated in Article 28H (1), "Every person is entitled to live prosperous physically and spiritually, to have a place to reside, and to acquire a good and healthy living environment as well as be entitled to obtain healthcare." Paragraph (2), "Every person is entitled to receive ease and special treatment to obtain the same opportunity and benefit to achieve the equality and the justice." Paragraph (3), "Every person shall be entitled to social security that enables his/her integral selfdevelopment as a dignified human being." Paragraph (4), "Every person shall be entitled to the personal property, and such property rights shall not be taken over arbitrarily by whomsoever."

i. The Rights in the category of non-derogable rights, cultural rights, and affirmation of protection, respect and fulfillment of human rights are the responsibility of the Government, as well as human rights guarantees in legislation regulated in Article 28I Paragraph (1), "The right to live, the right to not to be tortured, the right of freedom of 
thought and conscience, the right to be recognized as a person before the law, and the right not to be prosecuted under a retroactive law are human rights that cannot be reduced under any circumstances whatsoever". Paragraph (2), "Every person is entitled to be free from discriminative treatment on whatsoever basis and is entitled to acquire protection against such discriminative treatment." Paragraph (3), "The cultural identity and the right of traditional societies shall be respected in harmony with the development of the age and the civilizations." Paragraph (4), "The protection, the advancement, the enforcement and the fulfillment of human rights shall be the responsibility of the state, particularly the government." Paragraph (5), "For the enforcement and the protection of human rights by the principle of a democratic state based on the law, the execution of human rights shall be guaranteed, regulated, and set out in statutory rules and the regulations."

j. $\quad$ The Limitations of the State, Article 28J Paragraph (1) regulated that "Every person shall respect the human rights of the others in the order of life of the society, nation, and state." Paragraph (2), "In the exercise of his/her rights and freedom, every person shall abide by the limitations to be stipulated by the laws with the purpose of solely guaranteeing the recognition as well as the respect for the rights and the freedoms of the others and in order to comply with just demands in accordance with the considerations for morality, religious values, security, and public order in a democratic society". In the practice, this limitation has been defined in absolute terms by the Constitutional Court which covers all human rights, including rights which part of non-derogable rights, such as the right to life (in terms of commit crimes of extraordinary crime) as already qualified through the Constitutional Court Decision Number 2-3 / PUU-V / 2007 concerning Review of Law No. 22 on 1997 of Narcotics.

The important thing to note as the progress in the struggle to uphold human rights is the affirmation in Article 28I Paragraph (4) that the protection, the promotion, the enforcement, and the fulfillment of human rights are the responsibility of the state, especially the government. This is a form of the assertion that the human rights bearer is Human, while the bearer of obligations and responsibilities is the State (undertaken by the Government). This should be understood by every party, especially by the government (as the authorized holder of the State), so that in formulating norms (rules), taking actions/policies, the government should always reflect the protection of human rights. Indeed, in the context of Constitutional Law, since classical times, the affirmation of the protection of human rights has become the main study in constitutionalism and is the essence of the Constitution in every State. As stated earlier in the constitutionalism, the 
main principle is the limitation of government power and the protection of human rights. It can be interpreted that there are two important entities in the country that always face the Government (as the party that holds the authority and exercises the real power of the State) even in certain cases the government in action is the representation of the State, which is dealing with Human in general and individual which are the owner of human rights and citizen/civil rights. This is the urgency of the Constitution to become the first and the prime instrument in ensuring that human rights are respected, protected and fulfilled by the State. Although the foundation of human rights is universal, without the guarantee and the protection of the national Constitution, it will be very difficult to be applied. Even formulations that have been firm and clear just as in the provisions of the constitutional articles are categorized as non-derogable rights, but it still can be interpreted differently.

\section{Implementation of the Constitutional Court Function as "the Protector of Human Rights"}

The amendment of the 1945 Constitution is an important moment to seek the realization of a better nation and state life. This amendment has resulted in changes to the system, structure, mechanisms, and institutions of the state. It is not only due to changes to the provisions governing the institutional state but also because of changes in the paradigm of law and state administration. Some of the fundamental principles include the assertion that Indonesia is a state of the law with constitutional supremacy, a presidential system, the separation of powers, checks and balances, uphold the protection of human rights and the rights of the citizens. ${ }^{27}$ According to the logic of constitutionalism, a good constitution must provide a mechanism of mutual control between and institutions of state power and a means of guaranteeing the protection and the fulfillment of human rights, as well as instruments and mechanisms to restore rights in the event of a violation thereon. It is in line with Bagir Manan's view which explains that:

"As the consequences of the norm level principle and the supremacy of the constitution, there must be a mechanism to protect and ensure that the principle is not disregarded or violated. This mechanism is the judicial review of any statutory regulations, policies or other governmental actions against legislation or policies or other governmental actions to the higher

\footnotetext{
27 Jimly Asshiddiqie, "Hubungan antara Lembaga Negara Pasca Perubahan UUD 1945 (The Relation Between the State Institutions After the Amendment of the 1945 Constitution. Translated by the Authors)". Paper on Pendidikan dan Latihan Kepemimpinan (Diklatpim) Tingkat I Angkatan XVII Lembaga Administrasi Negara, Jakarta, 30 Oktober 2008.
} 
level of legislation, or the Constitution. Without these consequences, the order of the norm level principle will be meaningless." 28

The Constitutional Court is a State institution whose powers, and the Constitution determines authorities. The Constitutional Court is not an organ of law but an organ of the Constitution. Thus, the basis used by the Constitutional Court in carrying out its constitutional duties and authorities is the constitution itself. Even if laws and other legislation, by the principle of legality, must be obeyed by every person and every institution as subjects in national law, all such laws and regulations should be understood in a sense as long as they are not contradictory to the 1945 Constitution. ${ }^{29}$ The establishment of the Constitutional Court is influenced by the European law system (Civil Law), which gives authority to different institutions (outside the Supreme Court) to decide constitutional cases. Therefore, the procedure of constitutional review (especially an Act and other legislation) is done by one court so that the system is known as centralization, while the test method is called "principaliter." "30

The Constitutional Court is an independent judicial actor, established by the Third Amendment to the 1945 Constitution to administer the judiciary and to uphold law and justice in addition to the Supreme Court. According to Bagir Manan, independent judicial power is defined as independent of the influence of governmental power, ${ }^{31}$ it has to be free even from other powers outside the government. Based on Article 24C Paragraph (1) The Constitutional Court has the authority to adjudicate at the first and final judgment on the following cases:

a. Reviewing an Act against the Constitution;

b. To judge the authority disputes of state institutions whose authorities are granted by the Constitution;

c. To judge on the dissolution of a political party; and

d. To judge on disputes regarding the results of a general election.

In addition to those authorities, Article 24C Paragraph (2) also states that the Constitutional Court shall render a judgment on the petition from the House of Representative regarding an alleged violation to the President and the Vice President according to the Constitution. Based on its authority, the Constitutional Court is formed to guarantee and to ensure that the

\footnotetext{
${ }^{28}$ Bagir Manan, Op.Cit., pp. 207-208.

${ }^{29}$ Ibid.

${ }^{30}$ Paulus Efendi Lotulung, Op.Cit., p. 19.

31 Rahayu Prasetyaningsih, Penafsiran Konstitusi oleh Mahkamah Konstitusi Menuju Keadilan Substantif (The Interpetation of Constitution by the Constitutional Court Towards Substantive Justice. Translated by The Authors), Jurnal Konstitusi, Mahkamah Konstitusi dan Pusat Kebijakan Negara Fakultas Hukum Universitas Padjadjaran, 3 (1), (2011), p.134.
} 
constitution as the supreme law can be enforced. ${ }^{32}$ In line with this, the existence of the Constitutional Court as the organizer of the judicial authority strongly supports the growth and the development of human rights. ${ }^{33}$ According to Jimly Asshiddiqie, the Constitutional Court has functioned as follows:

a. The guardian of the constitution. It is by the basis of existence to maintain the implementation of the Constitution;

b. The final interpreter of the constitution;

c. The Guardian of democracy by protecting minority rights;

d. The Protector of the citizen's constitutional rights;

e. The Protector of human rights. ${ }^{34}$

The function of the Constitutional Court as the protector of human rights does not stand alone. The exercise of those functions shall be placed within the framework of the independent judiciary system. According to Bagir Manan, the freedom of the Constitutional Court as the organizer of judicial power has two meanings:

a. The judge is independent, free from the influence of any person and institution, whether executive or legislative, including the judicial elements themselves and the influence from outside of the government such as public opinion press and so forth.

b. Independence and freedom of judges are only limited to the function of judges as executors of judicial power or on their judicial functions. ${ }^{35}$

Based on this opinion, the Constitutional Court cannot make efforts related to the protection of human rights outside the provisions that become its authority as regulated in Article 24C Paragraph (1) and Paragraph (2) of the 1945 Constitution namely:

a. Reviewing an Act against the Constitution

The power of the Constitutional Court to reviews contradictory Acts to the 1945 Constitution is the application of checks and balances system in Indonesia. As before, the legislation produced by the legislative organ, cannot be questioned by judicial institutions. With the competence of judicial power through the Constitutional Court in reviewing Acts, all courts and institutions of the State and other institutions shall be bound by the decision of the Constitutional Court. The judicial review places the Act as the object of the judiciary, which if the Act proves to be contradictory with the Constitution, then some of the materials or the whole of it could no

\footnotetext{
32 Jimly Asshiddiqie, Perkembangan dan Konsolidasi Lembaga Negara Pasca Reformasi (The Development and Consolidation of State Institution After the Reformation. Translated by the Authors), Jakarta: Konstitusi Press Second Printing, (2006), pp. 154-155.

${ }^{33}$ Bagir Manan, Op.Cit., p. 6.

${ }^{34}$ Jimly Asshiddiqie, Op.Cit., p. 211.

${ }^{35}$ Rahayu Prasetyaningsih, Loc.Cit.
} 
longer be bound to the public. Review of an Act can be done in a material sense (material toetsing) or informal sense (formeele toetsing). ${ }^{36}$ If the review is done on the material/substance of the Act, then the review is called a "material review." This material review is related to the existence of an Act that violates human rights and citizens constitutional rights. Whereas if the review was done other than to the material/substance of the Act, then it is called as "formal review."

The reviews of an Act against the Constitution is an attempt to examine the enforcement and the application of an Act whether that Act is harming human rights and the constitutional rights of the citizen or not. This is affirmed in the legal standing of each applicant when they filed the request to the Constitutional Court to prove that an Act has impaired his/her constitutional rights and civil rights and even the Act itself is on the contrary to the 1945 Constitution. In the case of judicial review of an Act against the Constitution, the applicant is a party who considers that an Act, namely has impaired their constitutional rights: ${ }^{38}$

a. Individuals of Indonesian citizens (this understanding has undergone expansion including foreigners who have a direct interest in the enactment of a law that harms his/her human rights);

b. The unity of indigenous people or tribal communities as long as it is alive and by the development of society and the principle of NKRI regulated in the Act;

c. Public or private legal entities; or

d. State institutions.

\section{To judge the authority disputes of state institutions whose authorities are granted by the Constitution;}

The dispute over the authority between state institutions has a limit in the 1945 Constitution that the state institution in this context is only a state institution whose authority is granted by the 1945 Constitution. Therefore, regarding state institutions that can apply to the Constitutional Court, it can be seen in the 1945 Constitution of state institutions which has its authority directly from the 1945 Constitution, because the Constitution regulates the state organization and its authority. That the state institution must constitute constitutional organs which are either constituted based on the constitution or directly authorized to be regulated and derived from the Constitution. This is the only authority of the Constitutional Court which is not directly related

\footnotetext{
${ }^{36}$ Sri Soemantri, Hak Uji Material di Indonesia (Judicial Review in Indonesia. Translated by the Authors), Bandung: Alumni, (1997), p. 6.

${ }^{37}$ Jimly Asshiddiqie, Op.Cit., p. 589.

${ }^{38}$ Article 51 Paragraph (1) Act Number 24 Year 2003 Concerning The Constitutional Court.
} 
to Human Rights but is only related to the constitutional authority of the State institution by the Constitution.

\section{To Judge on the Dissolution of Political Parties;}

The petitioner for dissolution of a political party is the government of the Republic of Indonesia. Political parties are a form of freedom of the association and the assembly which is also guaranteed in the 1945 Constitution. However, in certain cases, the State (government) may limit this right to guarantee the rights and privacy of the religious consciousness, religious values, security and common order in a democratic society. The Constitutional Court is an impartial judicial body in deciding whether the right of association and assembly of political parties have been exercised under the constitution or not. The authority to decide the dissolution of political parties is related to the freedom of every person or citizen to associate and assemble. Through its verdict the Constitutional Court is the determinant and the authority of a political party formed by a group of Indonesian citizens as a form of freedom of association and assembly of the ideology, principles, objectives, programs and activities of political parties that have been in accordance with the Law of the Republic of Indonesia Year 1945 .

\section{To Judge on Disputes Regarding the Result of a General Election}

Elections are a means of manifesting democracy and the implementation of the right to vote and be elected as a political right. Democratic and basic elections are a reflection of the quality of elections that determine the legitimacy of representatives of the people who sit in the legislative and the executive institutions. To measure whether the implementation of it has been by the Constitutional Court or not as a judiciary in the constitutional field to decide upon it. The Constitutional Court conducted the verdict of general election disputes is an effort to decide whether the election is truly a manifestation of democracy and the recognition of human rights in the political front is implemented based on the principle of General Election in Indonesia (direct, public, free, confidential, honest and fair), Pancasila and the 1945 Constitution accordingly. This dispute relates to the determination of the results of national elections conducted by the KPU which resulted in the DPD, DPR or DPRD membership or influencing the Presidential/Vice Presidential candidate stepping on the second rotation of the Presidential/Vice Presidential election or influencing the elected candidate to the President/Vice President. Mostly, this has happened because of the mistakes in the election vote counting. 
6. The Constitutional Court is obliged to render a judgment on the petition from the People Representatives Council regarding alleged violations by the President and Vice President according to the Constitution.

Article 7A The 1945 Constitution of The Republic of Indonesia states that:

"The President and/or the Vice President can be discharged during his/her term of office by the People's Consultative Assembly at the proposal of the People's Representative Council, either if proven to have committed a violation of law in the form of treason against the state, corruption, bribery, other felonies or disgraceful acts or if proven that he/she is no longer qualified as President and/or Vice President.

Moreover, Article 7B Paragraph (1) states that,

"A proposal for the discharge of a President and/or a Vice President may be submitted by the People's Representatives Council to the People's Consultative Assembly only by first submitting a request to the Constitutional Court to examine, to adjudicate, and to judge on the petition of the People's Representative Council that the President/Vice President has committed a violation of law by an act of treason against the state, corruption, bribery, other felonies, or disgraceful acts; and / or the petition that the President and/or the Vice President no longer meets the qualification as President and/or Vice President."

Both of the articles above indicate that the discharge of a President and Vice President during his/her terms of office can only be done when the President and Vice President are proven to do the following acts:

1. Violation of law (criminal law); in the form:
a. Treason;
b. Corruption;
c. Bribery;
d. Other felonies.

2. Disgraceful acts, as measured by moral and ethical principles.

3. The President and Vice President no longer meet the qualification as President and Vice President (categorized as administrative reasons, by the conditions affirmed in the 1945 Constitution and the General Elections law).

The obligation of the Constitutional Court to decide upon the opinion of the People's Representatives Council is also a manifestation of the enforcement of the constitution as the supreme law of the land, and the protection of the individual rights of the Acting President and/or Vice President not to be removed from office only by political considerations. Based on these authorities and obligations, the Constitutional Court performs its roles and functions as "the protector of Human Rights" in Indonesia 
constitutional state administration system towards the democratic society that uphold the human rights.

\section{Conclusion}

1. The urgency of the Amendment of the 1945 Constitution of the Republic of Indonesia as the written constitution has brought progress in respecting, protecting and fulfilling human rights in Indonesia. As a written constitution, the 1945 Constitution of the Republic of Indonesia is an instrument for determining a norm (law), action or government policy whether it is violating/not violating human rights and constitutional rights of the citizen. Moreover, it is a very important basic instrument in ensuring that the State is protecting the Human Rights accordingly. It can be seen from the provisions that have regulated human rights materials starting from the affirmation of the fundamental rights, individual rights, social rights, rights of solidarity, and even affirmation of rights included in the category of non-derogable rights in the Second Amendment of the 1945 Constitution. This fact shows progress on the level of legislation and protection of human rights in Indonesia so that the post-amendment 1945 Constitution may be referred to as the Constitution of Human Rights.

2. The implementation of the function of the Constitutional Court as "the Protector of Human Rights" shall be conducted through the authority granted by the 1945 Constitution namely the review of an Act against the Constitution, deciding the dissolution of political parties, deciding disputes over election results, and through the obligation of the Constitutional Court to decide upon the opinion of the House of Representatives violations committed by the President and/or Vice President under the Constitution. While the authority to decide the dispute of the state institutions is not directly related with the human rights because it is only related to the institutional authority of the state.

\section{Bibliography}

\section{A. Book}

Asshiddiqie, Jimly. (2008). Pokok-Pokok Hukum Tata Negara Indonesia Pasca Reformasi ((Principles of Constitutional Law in PostReform Indonesia. Translated by the Author). Jakarta: Bhuana Ilmu Populer Kelompok Gramedia.

Asshiddiqie, Jimly. (2002). Konstitusi dan Konstitusionalisme Indonesia di Masa Depan (The Future of Indonesian Constitution and 
Constitutionalism. Translated by the Authors). Jakarta: Pusat Studi Hukum Tata Negara, Fakultas Hukum, Universitas Indonesia.

Asshiddiqie, Jimly. (2006). Perkembangan dan Konsolidasi Lembaga Negara Pasca Reformasi (The Development and Consolidation of State Institutions After the Reformation. Translated by the Authors). Jakarta: Konstitusi Press

Asshiddiqie, Jimly. (2008). Gagasan Dasar tentang Konstitusi dan Mahkamah Konstitusi (Basic Idea on Constitution and Constitutional Court. Translated by the Authors), in Sri Rahayu Oktoberina and Niken Savitri (Editors) Butir-Butir Pemikiran Dalam Hukum, Memperingati 70 Tahun Prof. Dr. B. Arief Sidharta (Pieces of Thoughts on Law, Celebrating the 70 Years of Prof. Dr. B. Arief Sidharta. Translated by the Authors). Bandung: Revika Aditama.

Asshiddiqie, Jimly. (2009). Pengantar Ilmu Hukum Tata Negara (Introduction to the Indonesian Constitutional Law. Translated by the Authors). Bandung: Rajagrafindo Persada.

Dahlan Thaib, Jazim Hamidi, and Nikmatul Huda. (2008). Teori dan Hukum Konstitusi (Theory and Constitutional Law. Translated by the Authors). Jakarta: Rajagrafindo Persada.

Knut D. Suparman Marzuki, Eko Riyadi (Editors). (2008). Hukum Hak Asasi Manusia (The Human Rights Law. Translated by the Authors) / Rhona K. M. Smith, et.al., Pusat Studi Hukum dan Hak Asasi Manusia. Yogyakarta: Universitas Islam Indonesia.

Latif, Abdul. (2009). Fungsi Mahkamah Konstitusi Upaya Mewujudkan Negara Hukum Demokrasi (The Constitutional Court Function to Fulfill the Democratic Law State. Translated by the Authors). Jakarta: Total Media.

Manan, Bagir. (1995). Pertumbuhan dan Perkembangan Konstitusi suatu Negara (Growth and Development of the Constitution of a State. Translated by the Authors). Bandung: Mandar Maju.

Manan, Bagir. (2004). Teori dan Politik Konstitusi (Theory and Political Constitution. Translated by the Authors), Yogyakarta: FH-UII Press.

Marzuki, Peter Mahmud. (2005). Penelitian Hukum (Law Research. Translated by the Authors). Jakarta: Kencana.

Nasution, Adnan Buyung. (1995). Aspirasi Pemerintahan Konstitusional di Indonesia: Studi Sosio Legal atas Konstituante 1956-1959 (The Aspiration for Constitutional Government in Indonesia A SocioLegal Study of the Indonesian Konstituante, 1956-1959. Translated by the Authors). Jakarta: Pustaka Utama Grafiti. 
Prodjodikoro, Wirdjono. (1989). Asas-Asas Hukum Tata Negara di Indonesia (The Principles of Indonesian Constitutional Law. Translated by the Authors). Jakarta: Dian Rakyat

S. Lev. Daniel. (1990). Hukum dan Politik di Indonesia: Kesinambungan dan Perubahan (Law and Politics in Indonesia: Sustainability and Change. Translated by the Authors). Jakarta: LP3ES.

Soemantri M, Sri. (2009). Prosedur dan Sistem Perubahan Konstitusi (The Procedure and System of Constitution Amendment. Translated by the Authors). Bandung: Alumni.

Soemantri, Sri. (1997). Hak Uji Material di Indonesia (Judicial Review in Indonesia. Translated by the Authors). Bandung: Alumni.

Yamin, Muh. (1951). Proklamasi dan Konstitusi Konstitusi (Proclamation and Constitution. Translated by the Authors). Jakarta: Djambatan

\section{B. Journal and Paper}

Jimly Asshiddiqie, Hubungan antara Lembaga Negara Pasca Perubahan UUD 1945 Hubungan antara Lembaga Negara Pasca Perubahan UUD 1945, (The Relation Between the State Institutions After the Amendment of the 1945 Constitution. Translated by the Authors), Paper on Pendidikan dan Latihan Kepemimpinan (Diklatpim) Tingkat I Angkatan XVII Lembaga Administrasi Negara. Jakarta, 30 Oktober 2008.

Muhtaj, Majda El. (2002). Jaminan Konstitusi atas Hak Asasi Manusia : Kajian terhadap UUD yang Pernah Berlaku di Indonesia Sejak Tahun 1945 Sampai Dengan Amandemen ke Empat Tahun 2002 (Constitutional Guarantee on Human Rights : Study to Indonesian Constitution Since 1945 Until The Fourth Amendment in 2002. Translated by the Authors), Medan: Thesis, Post Graduated Program The University of North Sumatera.

Rahayu Prasetyaningsih, Penafsiran Konstitusi oleh Mahkamah Konstitusi Menuju Keadilan Substantif (The Interpetation of Constitution by the Constitutional Court Towards Substantive Justice. Translated by The Authors), Jurnal Konstitusi, Mahkamah Konstitusi dan Pusat Kebijakan Negara Fakultas Hukum Universitas Padjadjaran, 3 (1), (2011). 


\section{Legislations}

The 1945 Constitution of the Republic of Indonesia

Republic of Indonesia Law No. 1 on 2003 of the Constitutional Court 